\title{
Inflammatory Bowel Disease
}

Crohn's disease and ulcerative colitis

Jan Wehkamp, Martin Götz, Klaus Herrlinger, Wolfgang Steurer, Eduard F. Stange

\section{SUMMARY}

Background: Inflammatory bowel diseases are common in Europe, with prevalences as high as 1 in 198 persons (ulcerative colitis) and 1 in 310 persons (Crohn's disease).

Methods: This review is based on pertinent articles retrieved by a search in PubMed and in German and European guidelines and Cochrane reviews of controlled trials.

Results: Typically, the main clinical features of inflammatory bowel diseases are diarrhea, abdominal pain, and, in the case of ulcerative colitis, peranal bleeding. These diseases are due to a complex immunological disturbance with both genetic and environmental causes. A defective mucosal barrier against commensal bowel flora plays a major role in their pathogenesis. The diagnosis is based on laboratory testing, ultrasonography, imaging studies, and, above all, gastrointestinal endoscopy. Most patients with Crohn's disease respond to budesonide or systemic steroids; aminosalicylates are less effective. Refractory exacerbations may be treated with antibodies against tumor necrosis factor (TNF) or, more recently, antibodies against integrin, a protein of the cell membrane. In ulcerative colitis, aminosalicylates are given first; if necessary, steroids or antibodies against TNF- $\alpha$ or integrin are added. Maintenance therapy to prevent further relapses often involves immunosuppression with thiopurines and/or antibodies. Once all conservative treatment options have been exhausted, surgery may be necessary.

Conclusion: The treatment of chronic inflammatory bowel diseases requires individually designed therapeutic strategies and the close interdisciplinary collaboration of internists and surgeons.

\section{Cite this as:}

Wehkamp J, Götz M, Herrlinger K, Steurer W, Stange EF: Inflammatory bowel disease: Crohn's disease and ulcerative colitis. Dtsch Arztebl Int 2016; 113: 72-82. DOI: $10.3238 /$ arztebl.2016.0072

Department of Internal Medicine I - Gastroenterology, Hepatology, Infectiology, University Hospital of Tübingen: Prof. Dr. med. Wehkamp, Prof. Dr. med. Götz

Asklepios Klinik Nord - Heidberg, Hamburg: Prof. Dr. med. Herrlinger

Department of Internal Medicine I (Gastroenterology, Hepatology and Endocrinology), Robert-Bosch-Krankenhaus, Stuttgart: Prof. Dr. med. Steurer, Prof. Dr. med. Stange rohn's disease and ulcerative colitis, the two varieties of inflammatory bowel disease (IBD), both tend to arise in early adulthood, but can in fact arise at any age from early childhood onward. Their diagnosis is often delayed despite their prominent manifestations, including diarrhea, abdominal pain, and, in ulcerative colitis, peranal bleeding. Crohn's disease can affect the entire gastrointestinal tract transmurally, from the mouth to the anus, while ulcerative colitis mainly affects the colonic mucosa. The clinical picture is rounded out by extra-intestinal manifestations in the joints, eyes, and skin, which can arise before the bowel disease does. An extensive monograph on IBD was published recently (1). For the special features of IBD in children, the reader is referred to another recent review in Deutsches Ärzteblatt International (2).

IBD are attracting increased attention at present for a number of reasons.

One reason is that that these diseases are far from rare, with prevalences of up to 1 in 198 persons for ulcerative colitis and 1 in 310 persons for Crohn's disease (3). In most epidemiologic studies, an increasing incidence has been seen. A further reason is that their treatment has become more complex with the introduction of monoclonal antibodies against TNF and integrins.

\section{Learning objectives}

This article is intended to acquaint readers with:

- new pathophysiological concepts in IBD

- the fundamentals of diagnostic evaluation

- options for pharmacotherapy

- the fundamentals of surgical treatment.

\section{Methods}

This review is based on a literature search in PubMed employing the terms "Crohn's disease" and "ulcerative

\section{Age at onset}

Crohn's disease and ulcerative colitis, the two varieties of inflammatory bowel disease (IBD), both tend to arise in early adulthood, but can in fact arise at any age from early childhood onward. 

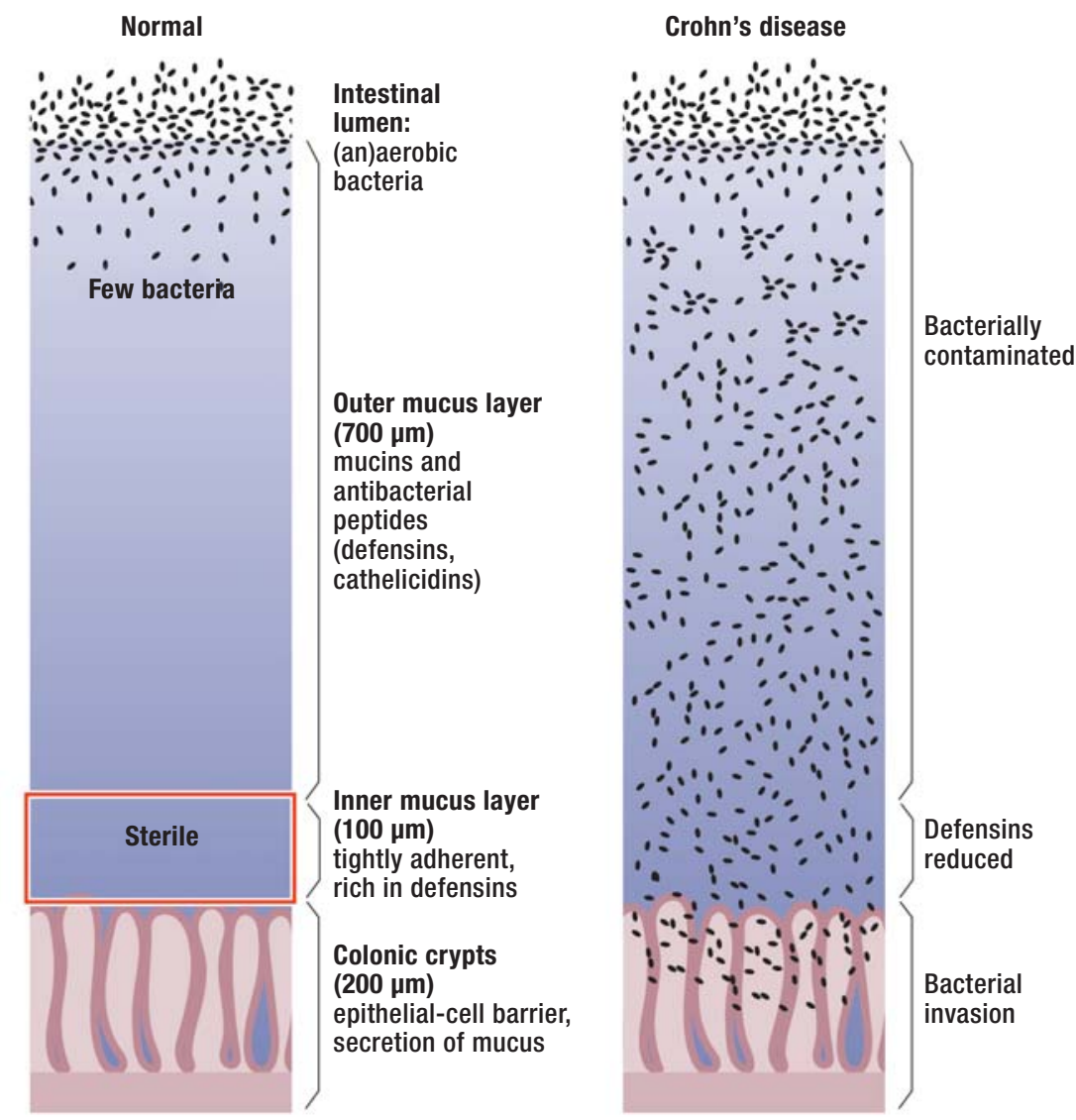

\section{Ulcerative colitis}

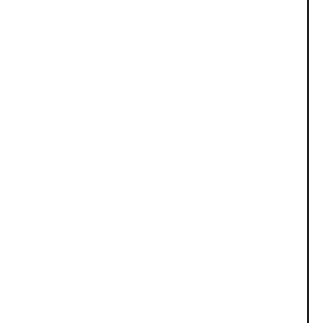

Thinned mucus layer

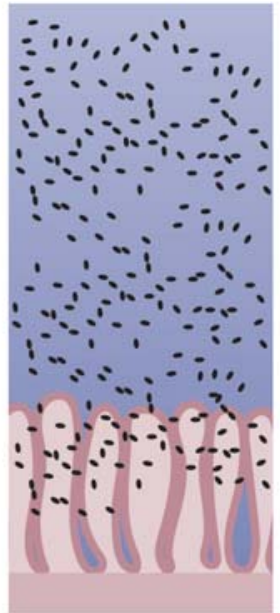

colitis," and on the current German $(4,5)$ and European (6-9) guidelines for these two conditions. The currently recommended diagnostic evaluation of IBD is mainly derived from case series; the treatment recommendations are generally based on the findings of clinical trials and meta-analyses of clinical trials, preferably Cochrane Reviews.

\section{The pathophysiology of IBD}

Explanatory concepts for IBD have changed in recent years. Twin studies (e1) have shown that a genetic predisposition (10), as opposed to environmental factors, plays a larger role in Crohn's disease than in ulcerative colitis. More than 160 risk genes are associated with Crohn's disease; most of them affect the interaction of microbes with the bowel (e2) and are dependent on phenotype (e3). Important environmental factors include antibiotic consumption during childhood and adolescence and, for Crohn's disease, cigarette smoking (e4). The commensal microflora of the bowel are now thought to play a central role in the induction and maintenance of the chronic inflammatory process (11-13, e5, e6). The normally peaceful coexistence of about $10^{14}$ micro-organisms of at least 1000 bacterial species in the human gastrointestinal tract is an amazing phenomenon, particularly in the terminal ileum and

\section{Pathophysiology}

Twin studies have shown that a genetic predisposition, as opposed to environmental factors, plays a larger role in Crohn's disease than in ulcerative colitis.

\section{Environmental factors}

Important environmental factors include antibiotic consumption during childhood and adolescence and, for Crohn's disease, cigarette smoking. 
Figure 2: Typical endoscopic and tomographic findings in chronic inflammatory bowel disease.

a) Mild ulcerative colitis: edema and erythe$\mathrm{ma}$, with broken light reflexes from the granulated colonic mucosa.

b) Terminal ileitis in Crohn's disease: partly aphthous (8 o'clock), partly confluent ulcerations (2 and 4 o'clock) of the small bowel mucosa.

c) Contrast-enhanced computerized tomography (CT): massively dilated cecum with coprostasis and thickening of the wall of the ascending and transverse colon with loss of haustration in an acute, severe relapse of longstanding ulcerative colitis (kindly provided by PD Dr. C. Schraml, Department of Diagnostic and Interventional Radiology [Director, Prof. Dr. K. Nikolaou], Universitätsklinikum Tübingen).

d) Contrast-enhanced magnetic resonance enteroclysis: Crohn's disease, mixed inflammatory and fibrotic-stenotic changes in the terminal ileum (acknowledgement as above).
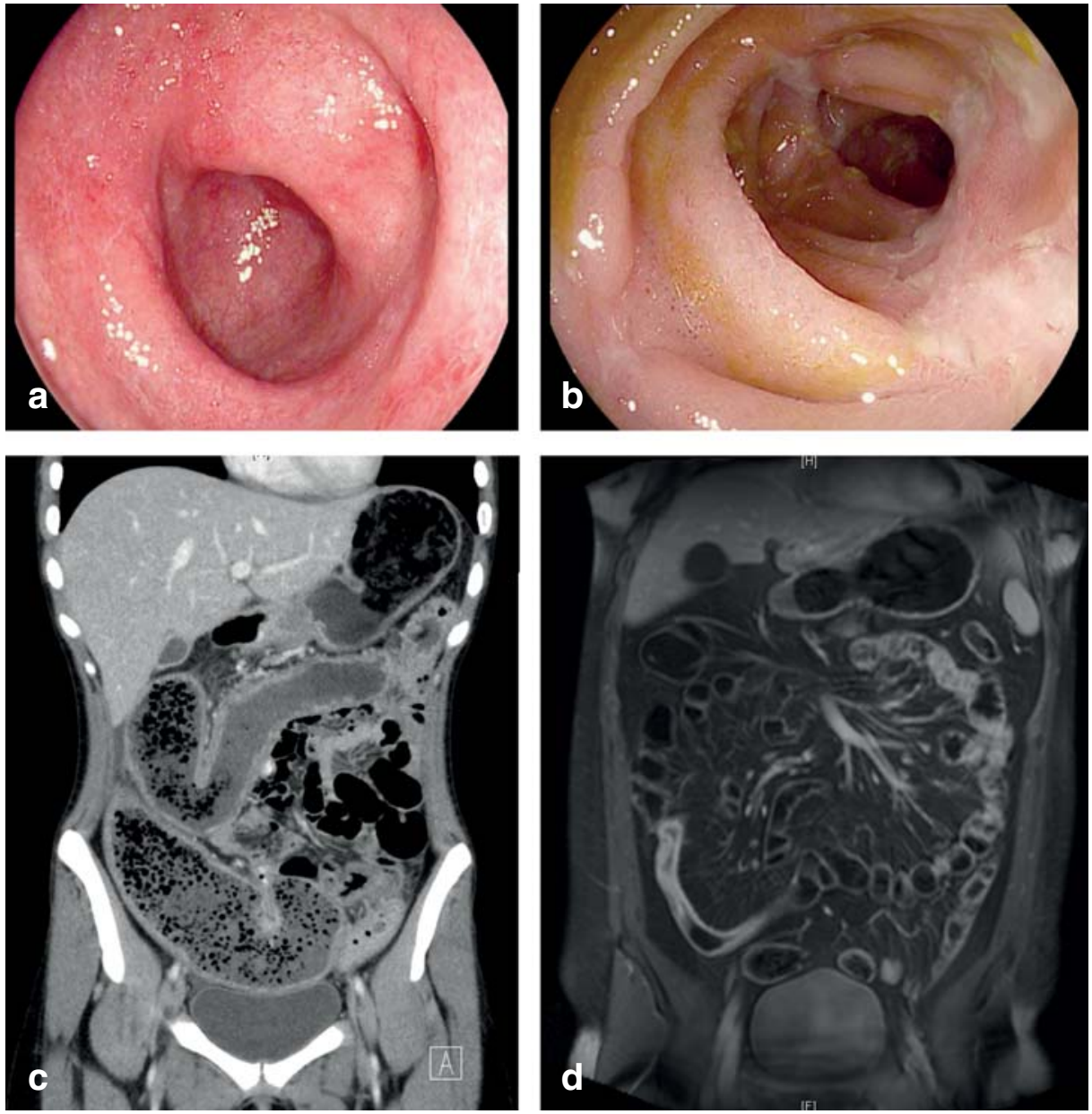

colon, which is the site where the bacterial concentrations are highest and where the manifestations of Crohn's disease and ulcerative colitis are most commonly found. There is a "dysbiosis" of the microflora (e7) of uncertain primary significance (e8); IBD patients, unlike normal individuals, have bacteria directly on and in their mucosal epithelium (12, e9, e10). The earlier interpretation of IBD as classic autoimmune diseases is obsolete (e11); instead, they are now thought of as complex barrier disorders. The mucosal barrier consists of the epithelial layer and the antibacterial mucus layer above it, which is made up of goblet cell mucins and epithelially secreted intrinsic peptide antibiotics (defensins) (Figure 1) (13, e12). In ulcerative colitis, a defective, thinned mucus layer is seen (e13). In Crohn's disease of the small intestine, the Paneth cells at the base of the crypts and defective defensin formation seem to play a central role (13-15).Various defects of bacterial recognition (NOD2), autophagy, endoplasmic reticulum stress, and monocyte function (e14) impair antimicrobial defenses and alter the microbiome $(14,15)$. Invading bacteria induce an inflammatory response involving both the innate immune cells (granulocytes, macrophages, dendritic cells) and the adaptive immune cells (T cells) $(16, \mathrm{e} 15)$.

\section{Autoimmune disease}

The earlier interpretation of IBD as classic autoimmune diseases is obsolete; they are now thought of as complex barrier disorders.

\section{The formation of defensins}

Various defects of bacterial recognition (NOD2), autophagy, endoplasmic reticulum stress, and monocyte function impair antimicrobial defenses and alter the microbiome. 
Evidence levels of treatment recommendations for chronic inflammatory bowel disease*

\begin{tabular}{|c|c|c|c|c|c|}
\hline \multicolumn{3}{|l|}{ Crohn's disease } & \multicolumn{3}{|l|}{ Ulcerative colitis } \\
\hline Involvement/course & Treatment & $\begin{array}{l}\text { Evidence } \\
\text { level }\end{array}$ & Involvement/course & Treatment* & $\begin{array}{l}\text { Evidence } \\
\text { level }\end{array}$ \\
\hline lleocecal involvement & $\begin{array}{l}\text { Budesonide } \\
\text { Mesalazine } \\
\text { Glucocorticoids (syst.) }\end{array}$ & $\begin{array}{l}\text { I } \\
\text { II } \\
\text { I }\end{array}$ & Proctitis & $\begin{array}{l}\text { Topical mesalazine } \\
\text { Plus topical steroids } \\
\text { Topical tacrolimus }\end{array}$ & $\begin{array}{l}\| \\
\| \\
\|\end{array}$ \\
\hline Colonic involvement & $\begin{array}{l}\text { Sulfasalazine } \\
\text { Glucocorticoids }\end{array}$ & i & $\begin{array}{l}\text { Left colitis, } \\
\text { if mesalazine-resistant }\end{array}$ & $\begin{array}{l}\text { Mesalazine (topical + systemic) } \\
\text { then glucocorticoids }\end{array}$ & $\begin{array}{l}\text { II } \\
\text { III }\end{array}$ \\
\hline Small-bowel involvement & Glucocorticoids & $\|$ & $\begin{array}{l}\text { Widespread involvement, } \\
\text { if mesalazine-resistant }\end{array}$ & $\begin{array}{l}\text { Mesalazine (topical + systemic) } \\
\text { then glucocorticoids }\end{array}$ & IIII \\
\hline Steroid-resistant course & $\begin{array}{l}\text { Anti-TNFa or anti-integrin } \\
\text { Antibodies }\end{array}$ & I & Severe course & Glucocorticoids i. v. & $\|$ \\
\hline $\begin{array}{l}\text { Maintenance of remission } \\
\text { (steroid-dependent) }\end{array}$ & $\begin{array}{l}\text { Azathioprine } \\
\text { 6-mercaptopurine } \\
\text { Methotrexate } \\
\text { Anti-TNFa antibodies } \\
\text { Anti-integrin antibodies }\end{array}$ & $\begin{array}{l}\text { I } \\
\text { II } \\
\text { II } \\
\text { I } \\
\text { I }\end{array}$ & $\begin{array}{l}\text { Steroid-resistant course } \\
\text { Maintenance of remission } \\
\text { if mesalazine-intolerant } \\
\text { if mesalazine-resistant or } \\
\text { steroid-dependent }\end{array}$ & $\begin{array}{l}\text { Cyclosporine } \\
\text { Infliximab } \\
\text { Tacrolimus } \\
\text { Mesalazine } \\
\text { then E. coli Nissle } \\
\text { then azathioprine/6- } \\
\text { mercaptopurine, anti-TNFa or } \\
\text {-integrin antibodies }\end{array}$ & $\begin{array}{l}1 \\
1 \\
11 \\
1 \\
1 \\
1\end{array}$ \\
\hline
\end{tabular}

* Evidence levels classified according to (4); syst., systemic.

\section{Diagnostic evaluation}

The (initial) diagnosis of IBD is made on the basis of history and physical examination, along with the laboratory values and the findings of endoscopic, histological, and radiological studies. No single feature establishes the diagnosis (6). Chronic diarrhea is a characteristic manifestation, with bloody diarrhea typifying ulcerative colitis (e16); abdominal pain and weight loss are also typical. For differential diagnosis, the patient should be specifically asked about food intolerance, drugs taken (including nonsteroidal antiinflammatory drugs [NSAID]), travel abroad, and cigarette smoking. IBD should be considered as a possible diagnosis in children with unexplained failure to thrive (2), nutritional deficiencies (particularly vitamin $\mathrm{B}_{12}$ deficiency), certain skin changes (erythema nodosum, pyoderma gangrenosum), and seronegative rheumatic joint pain (a possible extra-intestinal manifestation of IBD) (4).

The initial laboratory tests comprise a complete blood count (anemia and thrombocytosis indicate chronic inflammation), inflammatory parameters, and renal and hepatic function tests. The measurement of calprotectin, a neutrophil protein, in the stool is now standard (17). The calprotectin level is nonspecifically elevated in gastrointestinal inflammation but is a useful parameter for noninvasive treatment monitoring. Gastrointestinal infections (including Clostridium difficile) must be excluded at the outset and sometimes also in new exacerbations, as they can take an atypical course in patients who are under treatment for IBD (18).

Endoscopy is the gold standard for the initial diagnosis of IBD (Figure 1) (19). If Crohn's disease is suspected, the terminal ileum must be intubated, because most patients have mucosal changes there (e17). In severe exacerbations of ulcerative colitis, with maximum inflammation nearly always in the rectum, sigmoidoscopy often suffices for the acute evaluation. Histological examination yields important additional information; architectonic abnormalities confirm the diagnosis. In some cases, the two kinds of IBD can be distinguished from each other, and from other types of

\section{The clinical history}

No single feature establishes the diagnosis.

Chronic diarrhea is a characteristic manifestation, with bloody diarrhea typifying ulcerative colitis; abdominal pain and weight loss are also typical.

\section{Initial laboratory testing}

The initial laboratory tests comprise a complete blood count, inflammatory parameters, and renal and hepatic function tests. The measurement of calprotectin, a neutrophil protein, in the stool is now standard. 
bowel disease (e.g., infection) only on further follow-up, but over $90 \%$ of patients have a definite diagnosis 5 years after presentation (e18). The upper gastrointestinal tract should be evaluated by esophagogastroduodenoscopy with biopsy at the time of initial diagnosis (4), because extensive involvement with Crohn's disease confers a worse prognosis (e19). Ultrasonography and magnetic resonance enterography of the small intestine complete the initial diagnostic evaluation for the extent of disease (Figure 2). We also often use ultrasonography to monitor the course of disease (4), although MRI (or, in emergency cases, CT) is superior to ultrasonography for the demonstration of fistulae and abscesses (e20). MRI is also suitable for the evaluation of stenoses, showing not only their extent and prestenotic dilatation, but also wall thickening and perfusion (which can help distinguish fibrotic from inflammatory stenoses). This, in turn, is helpful in treatment planning, e.g., the decision whether to treat with anti-inflammatory drugs or to perform dilatation. Toxic megacolon can be a serious acute manifestation of ulcerative colitis; a plain abdominal x-ray demonstrating colonic dilatation over $6 \mathrm{~cm}$ without any distal stenosis is diagnostic.

Over the course of follow-up, a good clinical response to treatment is often associated with the normalization of previously pathological laboratory values. If there is a discrepancy, endoscopy can yield further information to be considered in the decision whether to intensify or modify the treatment. The high co-prevalence of irritable bowel syndrome in as many as one-third of all patients with IBD (5, e21, e22) must be considered when symptoms persist despite mucosal healing. If the clinical picture remains unclear, the entities to be ruled out include stenosis (particularly in Crohn's disease), carcinoma (particularly in ulcerative colitis, but in Crohn's disease as well), and infection (particularly in immune-suppressed patients; e.g., cytomegalovirus, Clostridium difficile). Starting 8-10 years after the initial manifestation of either type of IBD, colonoscopy should be used to monitor for dysplasia. Chromoendoscopic surveillance with methylene blue or indigo carmine is better than white-light endoscopy for this purpose (e23). There is not yet enough evidence to determine whether it is best to monitor endoscopically for dysplasia every $1-5$ years in risk-group-adapted fashion, as recommended in the European guidelines (19), or to do so every 1-2 years in all patients, as recommended by the German Society for Digestive and Metabolic Diseases (DGVS) (5). Circumscribed neoplastic lesions can be endoscopically resected regardless of their classification as sporadic or colitis-associated, as long as a complete resection, absence of tumor elsewhere in the bowel, and good further surveillance can be ensured (19).

The natural course of IBD is highly variable: a patient may experience a mild course after a severe initial episode, a slowly or episodically progressive condition, or chronically intermittent or persistent symptoms (e24-e26). After an initial acute episode, there is a $40 \%$ chance of a remitting course with prolonged phases of disease inactivity between episodes (e19). About 20\% of all patients develop steroid-refractory disease; the remainder are steroid-dependent, i.e., they rapidly develop recurrent disease when any attempt is made to lower the steroid dose. In population-based studies of ulcerative colitis, about half of all patients were oligosymptomatic or asymptomatic five years after the initial diagnosis (e27); in Crohn's disease, complications were more frequent, with a more severe effect on the quality of life (e17). It is debated whether IBD increase mortality (e28-e31), although it is clear that mortality is higher in patients who have both IBD and primary sclerosing cholangitis (e32).

\section{The treatment of IBD}

The pharmacotherapy of IBD as recommended in current guidelines is wholly based on the findings of controlled trials and meta-analyses. An overview of the evidence levels of the more important recommendations is given in Table 1. The treatment should always be adapted to the site, extent, and course of disease in the individual patient, with further adaptations guided by the clinical response; there is inadequate evidence to support basing treatment escalations on endoscopic findings alone. A strategy of immediate, maximal immunosuppression, including antibody administration, at the time of diagnosis has not been incorporated into the guidelines, as this would constitute overtreatment for many patients, with frequent adverse effects. Thus, the standard therapeutic strategy is clinically guided, stepwise treatment, beginning with relatively well-tolerated drugs and proceeding incrementally toward aggressive immunosuppression (eFigures 1 and 2). As the individual course of disease is unpredictable, clinical follow-up should be frequent, and the treatment should be escalated whenever there has been an unsatisfactory response. This strategy enables the early detection of disease complications, while avoiding the

\section{Imaging studies}

Endoscopy of the upper and lower gastrointestinal tract should be performed. Ultrasonography and magnetic resonance enterography complete the battery of imaging studies to be performed.

\section{Pharmacotherapy}

The standard strategy for pharmacotherapy is clinically guided, stepwise treatment, starting with well-tolerated drugs and proceeding incrementally toward aggressive immunosuppression. 
costly and unnecessary provision of antibody therapy to uncomplicated patients.

\section{Crohn's disease}

A therapeutic algorithm for the induction and maintenance of remission in Crohn's disease is shown in eFigure 1.

\section{Induction of remission in relapsing disease}

If the ileocecal region is involved, budesonide, a drug that works best topically, is the treatment of choice. A recent trial, however, showed that mesalazine ( $4.5 \mathrm{~g} /$ day) is equally effective against mild to moderate ileocecal involvement in Crohn's disease (20). Sulfasalazine is now only rarely used because of its adverse effects but can still be given to treat Crohn's colitis, particularly if the patient also has joint pain. Isolated involvement of the rectum or sigmoid colon can be treated locally with enemas, rectal foam, or suppositories containing steroids or aminosalicylates. If these options fail, the standard treatment of acute relapses is systemic steroid administration. The optimally effective dose is $1 \mathrm{mg}$ per kg of body weight (BW); once the symptoms have responded, the dose should be slowly reduced.

\section{Induction of remission in case of steroid resistance}

If the patient does not respond adequately to systemic steroid treatment, the anti-TNF $\alpha$ antibodies infliximab (21) and adalimumab (22) and the anti-integrin antibody vedolizumab (23) can be used. Infliximab is given intravenously, adalimumab subcutaneously; they are of equivalent efficacy and bring about remission in roughly half of all patients treated. The decision which of these two drugs to use is made according to the patient's preference, taking the mode of administration into account.

The anti-integrin antibody vedolizumab is the first drug in this substance class to be approved for the treatment of refractory Crohn's disease. It has few side effects; after six weeks of treatment, the remission rate is $14.5 \%$, compared to $6.8 \%$ with placebo $(p=0.02)$. The main advantage of this drug is long-term maintenance of remission (23).

\section{Maintenance of remission}

Treatment to maintain remission is not indicated for all patients, but only for those who have had a complicated course. Despite their frequent use for this purpose (e33), aminosalicylates are not effective for the maintenance of remission in Crohn's disease (although they are effective in ulcerative colitis) (24). Patients who become steroid-dependent or who have frequent relapses should be given permanent immunosuppressive therapy; the first line of treatment is one of the two thiopurine drugs, azathioprine or 6-mercaptopurine (25). If these are poorly tolerated, methotrexate is an alternative (e34). If a relapse has been successfully treated with anti-TNFo antibodies, this treatment can be continued to maintain remission (e35, e36). The treatment can be successfully switched to azathioprine in about half of all cases (e37); sometimes, combined long-term immunosuppression is necessary (a thiopurine plus anti-TNF $\alpha$ antibodies). In combined treatment, the thiopurine drug lessens the immunogenicity of the anti-TNF $\alpha$ antibodies and may therefore prevent the loss of their effect. The risks and benefits of such treatment must be carefully weighed, however, as opportunistic infections and lymphoma are markedly more frequent under combined immunosuppression (e38). Thus, immunosuppression with a single drug is desirable if the clinical situation permits. Continuation of the treatment with a thiopurine drug alone (after, e.g., six months of combined immunosuppression) has the further advantage that anti-TNF $\alpha$ antibodies can still be used to induce remission after the next relapse. Steroids generally should not be given to maintain remission. If the treatment fails, vedolizumab can be given, as mentioned above. In the postoperative setting, e.g., after ileocecal resection, metronidazole (e39), mesalazine (e40), or, in complicated cases, a thiopurine drug $(26, \mathrm{e} 40)$ or anti-TNF $\alpha$ antibodies (e41) can be given.

\section{Ulcerative colitis}

For patients with ulcerative colitis (as with Crohn's disease), the treatment should be individually tailored to the site, extent, and severity of illness, and adapted to the treatment response (5). A treatment algorithm incorporating these features is shown in eFigure 2 .

\section{Induction of remission in relapsing disease}

Mildly to moderately active proctitis is treated initially either with mesalazine suppositories (at least $500 \mathrm{mg}$ / day) or, alternatively, with mesalazine enemas or foam $(5,27$, e 42$)$. If this does not bring an adequate response, topical steroids can be given in addition. If these, too, are ineffective, tacrolimus suppositiories are a potential alternative, although only case series of their use are available to date (e43)
Induction of remission in Crohn's disease

If the ileocecal region is involved, budesonide, a drug that works best topically, is the treatment of choice. A recent trial, however, showed that mesalazine ( $4.5 \mathrm{~g} /$ day) is equally effective against mild to moderate ileocecal involvement.
Induction of remission in ulcerative colitis

Mildly to moderately active left colitis and pancolitis should be treated initially with mesalazine foam and/or enemas combined with oral mesalazine. 
TABLE 2

Symptomatic recurrence rates and reoperation rates depending on the site of primary surgery in Crohn's disease

\begin{tabular}{l|c|c}
\hline Site of primary surgery & $\begin{array}{c}\text { Rate of symptomatic } \\
\text { recurrences (\%) }\end{array}$ & $\begin{array}{c}\text { Rate of } \\
\text { reoperation (\%) }\end{array}$ \\
\hline Ileum and colon & 70 & 60 \\
\hline Colon only & 50 & 15 \\
\hline lleum only & 30 & 10 \\
\hline Anorectal & 30 & 30 \\
\hline
\end{tabular}

Mildly to moderately active left colitis and pancolitis should be treated initially with mesalazine foam and/or enemas combined with oral mesalazine (at least 3 g/day) (28).

If remission is not achieved, corticosteroids should be given systemically $(0.5-1.0 \mathrm{mg}$ prednisone equivalent) (5). A severe relapse generally necessitates hospitalization for intravenous steroid treatment.

\section{Induction of remission in case of steroid resistance}

If steroid therapy does not induce remission within 3-4 days, the remaining choice is between the use of calcineurin inhibitors, such as cyclosporine $(5 \mathrm{mg} / \mathrm{kgBW} /$ day) and tacrolimus (0.15 $\mathrm{mg} / \mathrm{kgBW} /$ day) (29), and anti-TNF $\alpha$ antibodies (infliximab, adalimumab, or golimumab) (5, e44). These two substance classes are about equally effective (30) Calcineurin inhibitors have the advantage of a much shorter half-life and, therefore, the option of switching to antibodies in case of a lack of response. Combining the two substance classes is contraindicated.

Vedolizumab has recently been found effective against ulcerative colitis as well (3), but it should be reserved for not very severe cases, in view of its relatively long latency of effect. At present, all patients with steroid-resistant ulcerative colitis should be seen in consultation by a surgeon, so that the option of colectomy and pouch creation can be considered.

\section{Maintenance of remission}

In general, aminosalicylates (preferably mesalazine) should be given to maintain remission in ulcerative colitis for at least two years, and even for life if indi- cated (32). The mode of administration depends on the site of disease; patients tend to dislike topical maintenance therapy with enemas or foam, and thus mesalazine is more commonly given by mouth (at least 1.5 $\mathrm{g} /$ day).

Mesalazine intolerance is rare (up to $15 \%$ of patients) (e45); in such cases, treatment with E. coli Nissle is of equivalent efficacy (e46). As in Crohn's disease, steroids are not suitable drugs for the maintenance of remission. They are contraindicated for longterm therapy because of their adverse effects.

Immune suppressants should be given in addition to aminosalicylates in case of frequent relapses, a single severe relapse, a relapse despite the use of reserve medication, or steroid dependence (5). Usually, after steroids are given, either azathioprine $(2.0-2.5 \mathrm{mg} /$ $\mathrm{kgBW} /$ day) or 6-mercaptopurine (1.0-1.5 mg/kgBW/ day) is given next; if this treatment is poorly tolerated, methotrexate can be used (despite a poor evidence base). The same holds for steroid dependence: after three months of immunosuppressive treatment, an attempt should be made to reduce the steroid dose slowly to zero.

In general, calcineurin inhibitors should also be switched to thiopurines, as long as the remission did not occur under immunosuppressive treatment, while anti-TNF $\alpha$ antibodies can continue to be given to maintain remission (e44). However, just as in Crohn's disease, the combination of anti-TNF $\alpha$ antibodies with a thiopurine is more effective than either substance alone (e47). Once again, vedolizumab (31) is an alternative for refractory disease.

\section{Surgery}

The surgical treatment of IBD is based largely on case series from major treatment centers. Controlled trials are the exception and have often been terminated prematurely because of slow recruitment (33).

Laparoscopic techniques have been found safe for the treatment of patients with IBD and confer the advantages of minimally invasive surgery (rapid recovery, little postoperative pain). They are therefore now used routinely (34).

\section{The surgical treatment of Crohn's disease}

$40 \%$ of patients with Crohn's disease undergo surgical treatment within 5 years of receiving the diagnosis, and $70 \%$ within 10 years. The surgical success rates 10 years after resection depend on the site of involvement:
Maintenance of remission in ulcerative colitis In general, aminosalicylates (preferably mesalazine) should be given to maintain remission in ulcerative colitis for at least two years, and even for life if indicated.

\section{Surgical technique}

Laparoscopic techniques have been found safe for the treatment of patients with IBD and confer the advantages of minimally invasive surgery (rapid recovery, little postoperative pain). They are therefore now used routinely. 
$90 \%$ for resection of a segment of ileum, $40 \%$ for ileocecal resection, and $85 \%$ for colonic resection (Table 2). The disease recurs at the anastomosis or in the segments neighboring the resected, diseased bowel segment in $10 \%$ to $60 \%$ of cases. $20 \%$ of patients who undergo surgical treatment need surgery again within 5 years (35).

The indications for surgical treatment in Crohn's disease, aside from the classic disease manifestation (terminal ileitis), include complex inflammatory changes along the entire small and large bowel, with the formation of abscesses, fistulae to the skin, to the bladder, and to other segments of the gastrointestinal tract, including the duodenum, stomach, and colon. The overarching principle of any surgical intervention is the removal of inflammatory foci, including drainage of abscesses and excision of fistulae, with maximal preservation of the normal bowel (36). Small-bowel ileus due to inflammatory blockage of the bowel lumen necessitates surgery in $5 \%$ to $10 \%$ of patients. In patients with chronic small-bowel obstruction with fixed stenoses, it can be difficult to determine preoperatively whether the cause is inflammatory or neoplastic. Crohn's disease increases the risk of small-bowel cancer-a very rare disease - by a factor of 10 to 12 compared to the general population (37), yet $70 \%$ of small cancers arising in patients with Crohn's disease are still not diagnosed until after surgery. Acute gastrointestinal bleeding rarely occurs in patients with Crohn's disease; its diagnosis and treatment are the same as in non-Crohn's disease patients.

The surgical treatments of choice for isolated smallbowel involvement are small-bowel segmental resection, stricturoplasty, ileocecal resection, and, in rare cases, gastroenterostomy (if the duodenum is involved) (e48, e49). In Crohn's colitis, the extent of surgery required depends on the pattern of involvement; either subtotal or total colectomy is usually performed, with proctocolectomy and terminal ileostomy being much less common (38). Interruption of intestinal continuity with a stoma (discontinuous resection) should remain a rare exception. Even complete bowel occlusion only rarely necessitates emergency surgery, and a conservative approach is valid, at least initially, in most cases. Endoscopic dilatation is preferable to repeated surgery for the treatment of accessible, short stenoses, mainly at the sites of anastomosis.

Perianal fistulae are among the more common complications of the disease. The main goal of treat- ment, along with preservation of sphincter function, is drainage of the fistula with the aid of a reinforcing loop or thread (seton), accompanied by pharmacotherapy with antibiotics and/or anti-TNF $\alpha$ antibodies, finally leading to closure of the fistula. Even today, such treatments are associated with recurrence rates of up to $70 \%$. In fistulae that have been active for many years, fistular carcinoma is a rare, but therefore all the more serious complication (38).

\section{The surgical treatment of ulcerative colitis}

Patients with ulcerative colitis are less likely than those with Crohn's disease to need surgical treatment for their disease at some point, with an overall likelihood of about $35 \%$. The fulminant form of ulcerative colitis ( $15 \%$ of cases) is characterized by $27 \%-57 \%$ mortality if primary treatment fails; on the other hand, surgery is hardly ever needed for purely left-sided colitis or proctitis (39).

Aside from absolute surgical indications, such as bowel perforation, severe bleeding, toxic megacolon with or without perforation, and colon carcinoma, the most common reasons for surgical treatment are an intractable disease course, the development of dysplasia, and morbidity due to extra-intestinal manifestations. The method of choice to treat active colitis is subtotal colectomy without any intestinal anastomosis, with a transient ileostoma, followed by proctectomy and pouch creation at a later time (a triple-staged procedure). On the other hand, during the inflammationfree period, the standard surgical treatment for ulcerative colitis is restorative proctocolectomy with ileo-pouchanal anastomosis (IPAA) and protective ileostoma (a double-staged procedure) (e50). This is the only curative surgical method available, although pouchitis arises again in about half of all cases.

\section{Conflict of interest statement}

Prof. Wehkamp has served as a paid consultant for MSD, Takeda, Novartis, Shire, Abbvie, and Ardeypharm. He has received reimbursement of meeting participation fees and of travel and accommodation expenses from Takeda. He has received payment for lecturing at continuing medical education events from the Falk Foundation, Abbvie, Takeda, MSD, Roche, Ferring, and Shire. He has received third-party research funding for carrying out clinical trials on behalf of Amgen, Novartis, Falk Pharma, and Abbvie. He is a member of the board of Defensin Therapeutics.

Prof. Götz has served as a paid consultant for MSD, Takeda, and Pentax. He has received reimbursement of meeting participation fees and of travel and accommodation expenses from Takeda, MSD, and Abbvie. He has received lecture honoraria from Takeda, MSD, Abbvie, and the Falk Foundation. He has received funding from Pentax for a research project that he initiated.

\section{Surgery for Crohn's disease}

$40 \%$ of patients with Crohn's disease undergo surgical treatment within 5 years of receiving the diagnosis, and $70 \%$ within 10 years.

\section{Perianal fistulae}

Perianal fistulae are among the more common complications of Crohn's disease. The main goal of treatment, along with preservation of sphincter function, is closure of the fistula. 
Prof. Herrlinger has served as a paid consultant for MSD and Takeda. He has received payment from Falk Pharma, Medac, and Abbvie for preparing continuing medical education events.

Prof. Stange has served as a paid consultant for Merck, Takeda, and Janssen. He has received reimbursement of travel and accommodation expenses, as well as lecture honoraria, from Abbvie, Falk, Ferring, and Takeda. He has received third-party research funding for carrying out clinical trials on behalf of Abbvie, Falk, Takeda, Celgene, Gilead, Amgen, Boehringer, Salix, and Pfizer.

Prof. Steurer states that no conflict of interest exists.

Manuscript submitted on 28 June 2015, revised version accepted on 14 December 2015

Translated from the original German by Ethan Taub, M.D.

\section{REFERENCES}

1. Stange EF: Entzündliche Darmerkrankungen. Stuttgart: Schattauer Verlag 2015

2. Buderus, S, Scholz D, Behrens R, et al.: Inflammatory bowel disease in pediatric patients - characteristics of newly diagnosed patients from the CEDATA-GPGE registry. Dtsch Arztebl Int 2015; 112: 121-7.

3. Molodecky NA, Soon IS, Rabi DM, et al.: Increasing incidence and prevalence of the inflammatory bowel diseases with time, based on systematic review. Gastroenterology 2012; 142: 46-54.

4. Preiss JC, Bokemeyer B, Buhr HJ, et al.: Updated German clinical practice guideline on "Diagnosis and treatment of Crohn's disease". Z Gastroenterol 2014; 52: 1431-84.

5. Dignass A, Preiss JC, Aust DE, et al.: Updated German guideline on diagnosis and treatment of ulcerative colitis. Z Gastroenterol 2011; 49: 1276-341

6. van Assche G, Dignass A, Panes J, et al.: The second European evidence-based consensus on the diagnosis and management of Crohn's disease: definitions and diagnosis. J Crohns Colitis 2010; 4: 7-27.

7. Dignass A, Van Assche G, Lindsay JO, et al.: The second European evidence-based consensus on the diagnosis and management of Crohn's disease: current management. J Crohns Colitis 2010; 4: 28-62.

8. Dignass A, Eliakim R, Magro, et al.: Second European evidencebased consensus on the diagnosis and management of ulcerative colitis part 1: definitions and diagnosis. J Crohns Colitis 2012; 6: 965-90.

9. Dignass A, Lindsay JO, Sturm A, et al.: Second European evidencebased consensus on the diagnosis and management of ulcerative colitis part 2: current management. J Crohns Colitis 2012; 6: 991-1030.

10. Rosenstiel P, Sina C, Franke A, Schreiber S: Towards a molecular risk map-recent advances on the etiology of inflammatory bowel disease. Semin Immunol 2009; 21: 334-345.

11. Duchmann R, May E, Heike M, et al.: T cell specificity and cross reactivity towards enterobacteria, bacteroides, bifidobacterium, and antigens from resident intestinal flora in humans. Gut 1999; 44: 812-8.

12. Moussata D, Goetz M, Gloeckner A, et al.: Confocal laser endomicroscopy is a new imaging modality for recognition of intramucosal bacteria in inflammatory bowel disease in vivo. Gut 2011; 60: 26-33.

13. Wehkamp J, Fellermann K, Herrlinger KR, Bevins CL, Stange EF: Mechanisms of disease: defensins in gastrointestinal diseases. Nat Clin Pract Gastroenterol Hepatol 2005; 2: 406-15.
14. VanDussen KL, Liu TC, Li D, et al.: Genetic variants synthesize to produce paneth cell phenotypes that define subtypes of Crohn's disease. Gastroenterology 2014; 146: 200-9.

15. Wehkamp J, Stange EF: Paneth's disease. J Crohns Colitis 2010; 4: 523-31.

16. Zundler S, Neurath MF: Immunopathogenesis of inflammatory bowel diseases: functional role of $T$ cells and T cell homing. Clin Exp Rheumatol 2015; 33: 19-28.

17. Mosli MH, Zou G, Garg SK, et al.: C-reactive protein, fecal calprotectin, and stool lactoferrin for detection of endoscopic activity in symptomatic inflammatory bowel disease Patients: A systematic review and meta-analysis. Am J Gastroenterol 2015; 110: 802-19;

18. Rahier JF, Magro F, Abreu C, et al.: Second European evidencebased consensus on the prevention, diagnosis and management of opportunistic infections in inflammatory bowel disease. J Crohns Colitis 2014; 8: 443-68

19. Annese V, Daperno M, Rutter MD, et al.: European evidence based consensus for endoscopy in inflammatory bowel disease. J Crohns Colitis 2013; 7: 982-1018.

20. Tromm A, Bungani I, Tomsová E, et al.: Budesonide $9 \mathrm{mg}$ is at least as effective as mesalamine $4.5 \mathrm{~g}$ in patients with mildly to moderately active Crohn's disease. Gastroenterology 2011; 140 : 425-34.

21. Targan SR, Hanauer SB, van Deenter SJ, et al.: A short-term study of chimeric monoclonal antibody $\mathrm{CA} 2$ to tumor necrosis factor alpha for Crohn's disease. N Engl J Med 1997; 337: 1029-35.

22. Hanauer SB, Sandborn WJ, Rutgeerts P, et al.: Human anti-tumor necrosis factor monoclonal antibody (adalimumab) in Crohn's disease: the CLASSIC-I trial. Gastroenterology 2006; 130: 323-33.

23. Sandborn WJ, Feagan BG, Rutgeerts P, et al.: Vedolizumab as induction and maintenance therapy for Crohn's disease. N Engl J Med 2013; 369: 711-21.

24. Akobeng AK, Gardener E: Oral 5-aminosalicylic acid for maintenance of medically-induced remission in Crohn's Disease. Cochrane Database Syst Rev 2005; (1): CD003715.

25. Prefontaine E, Sutherland LR, Macdonald JK, Cepoiu M: Azathioprine or 6-mercaptopurine for maintenance of remission in Crohn's disease. Cochrane Database Syst Rev 2009; (1): CD000067.

26. Gordon M, Taylor K, Akobeng AK, et al.: Azathioprine and 6-mercaptopurine for maintenance of surgically-induced remission in Crohn's disease. Cochrane Database Syst Rev 2014; (8): CD010233.

27. Marshall JK, Irvine EJ: Rectal aminosalicylate therapy for distal ulcerative colitis: a meta-analysis. Aliment Pharmacol Ther 1995; 9 : 293-300.

28. Marteau P, Probert CS, Lindgren S, et al.: Combined oral and enema treatment with Pentasa (mesalazine) is superior to oral therapy alone in patients with extensive mild/moderate active ulcerative colitis: a randomised, double blind, placebo controlled study. Gut 2005; 54: 960-5.

29. Schmidt KJ, Herrlinger KR, Emmrich J, et al.: Short-term efficacy of tacrolimus in steroid-refractory ulcerative colitis - experience in 130 patients. Aliment Pharmacol Ther 2013; 37: 129-36.

30. Laharie D, Bourreille A, Branche J, et al.: Ciclosporin versus infliximab in patients with severe ulcerative colitis refractory to intravenous steroids: a parallel, open-label randomised controlled trial. Lancet 2012; 380: 1909-15.

31. Feagan BG, Rutgeerts P, Sands BE, et al.: Vedolizumab as induction and maintenance therapy for ulcerative colitis. N Engl J Med 2013; 369: 699-710. 
32. Feagan BG, Macdonald JK: Oral 5-aminosalicylic acid for maintenance of remission in ulcerative colitis. Cochrane Database Syst Rev 2012 10: CD000544.

33. Rubin DT, Becker S, Siegler M: Ethical considerations for clinical trials in inflammatory bowel disease. Gastroenterol Hepatol 2014; 10: 37-41.

34. Indar AA, Efron JE, Young-Fadok TM: Laparoscopic ileal pouch-anal anastomosis reduces abdominal and pelvic adhesions. Surg Endosc 2009; 23: 174-177.

35. Fazio WW, Marchetti $F$, Church $M$, et al.: Effect of resection margins on the recurrence of Crohn's disease in the small bowel. A randomized controlled trial. Ann Surg 1996; 224: 563.

36. Fichera A, Michelassi F: Surgical treatment of Crohn's disease. J Gastrointest Surg 2007; 11: 791.

37. Michelassi F, Sultan S: Surgical treatment of complex small bowel Crohn disease. Ann Surg 2014; 260: 230-5.

38. Alós R, Hinojosa J: Timing of surgery in Crohn's disease: a key issue in the management. World J Gastroenterol 2008; 14: 5532-9.

39. Cohen JL, Strong SA, Hyman NH, et al.: Practice parameters for the surgical treatment of ulcerative colitis. Dis Colon Rectum 2005; 48 : 1997-2009.

\section{Corresponding author}

Prof. Dr. med. Eduard F. Stange

Zentrum Innere Medizin I

Gastroenterologie, Hepatologie und Endokrinologie

Robert-Bosch-Krankenhaus

Auerbachstr. 110,D- 70376 Stuttgart, Germany

Eduard.Stange@rbk.de

Supplementary material

For eReferences please refer to:

www.aerzteblatt-international.de/ref0516

eFigures:

www.aerzteblatt-international.de/16m0072

\section{Further information on GME}

This article has been certified by the North Rhine Academy for Postgraduate and Continuing Medical Education.

Deutsches Ärzteblatt provides certified continuing medical education (CME) in accordance with the requirements of the Medical Associations of the German federal states (Länder). CME points of the Medical Associations can be acquired only through the Internet, not by mail or fax, by the use of the German version of the CME questionnaire. See the following website: cme.aerzteblatt.de.

Participants in the CME program can manage their CME points with their 15-digit "uniform CME number" (einheitliche Fortbildungsnummer, EFN). The EFN must be entered in the appropriate field in the cme.aerzteblatt.de website under "meine Daten" ("my data"), or upon registration. The EFN appears on each participant's CME certificate.

This CME unit can be accessed until 1 May 2016, and earlier CME units until the dates indicated:

"The Presentation, Diagnosis, and Treatment of Sexually Transmitted Infections" (issue 1-2/2016) until 3 April 2016;

"Urosepsis - Etiology, Diagnosis, and Treatment" (issue 49/2016) until 28 February 2016. 


\section{Please answer the following questions to participate in our certified Continuing Medical Education program. Only one answer is possible per question. Please select the most appropriate answer.}

\section{Question 1}

What is the role of a genetic predisposition in the pathogenesis of

\section{Crohn's disease?}

a) The relative importance of a genetic predisposition, compared to environmental factors, is greater in Crohn's disease than in ulcerative colitis.

b) A genetic predisposition is more important in ulcerative colitis than in Crohn's disease.

c) A genetic predisposition plays no role in either Crohn's disease or ulcerative colitis.

d) A genetic predisposition is relevant only in female patients with Crohn's disease because of the pattern of transmission.

e) A genetic predisposition is equally important in Crohn's disease and ulcerative colitis.

\section{Question 2}

Which cells seem to play an especially important role in defective defensin formation in Crohn's disease with small-bowel involvement?

a) The cells of the submucosal plexus

b) The cells of the muscular layer beneath the submucosa

c) The cells of Peyer's plaques in the submucosa

d) The Paneth cells at the base of the crypts

e) The cells of the myenteric plexus

\section{Question 3}

What is a standard part of the initial diagnostic evaluation for suspected chronic inflammatory bowel disease?
a) X-ray of the abdomen in three planes
b) A thorough history to detect psychosocial causes
c) Comprehensive intracutaneous immune testing
d) A complete blood count
e) A prick test

\section{Question 4}

Which of the following constellations of clinical findings is typical of ulcerative colitis?

a) Chronic, usually bloody diarrhea, abdominal pain, and weight loss

b) Flatulence, black stool, and joint pain

c) Malodorous, yellow stool, alternating with constipation

d) Green stool and frequent diarrhea

e) Occasional painless constipation

\section{Question 5}

What laboratory test is of established value in the evaluation of chronic inflammatory bowel diseases?
a) Cystatin $\mathrm{C}$
b) Lysozyme
c) Vasopressin
d) Calprotectin
e) Anti-gliadin antibodies

\section{Question 6}

What type of imaging study is the gold standard for the initial diagnostic evaluation of chronic inflammatory bowel diseases?
a) Doppler ultrasonography
b) Endoscopy
c) Abdominal x-ray
d) Positron emission tomography
e) Computerized tomography

Question 7

In patients with ulcerative colitis, what is the first line of treatment for mild to moderate ulcerative proctitis?
a) Mesalazine suppositories
b) Mesalazine p.o.
c) Corticosteroids p.o.
d) Cyclosporine p.o.
e) Vedolizumab i. v.

Question 8

What is the drug of first choice for inducing remission in Crohn's disease with recurrent ileocecal involvement?
a) Prednisone (systemic steroids)
b) Vedolizumab
c) Tacrolimus
d) Sulfasalazine
e) Budesonide

Question 9

How long should aminosalicylates be continued in order to maintain remission in ulcerative colitis?
a) At least 1-3 weeks
b) At least 1-3 months
c) At least 4-6 months
d) At least 6-12 months
e) At least 2 years

\section{Question 10}

What is the standard surgical treatment of ulcerative colitis in the inflammation-free interval?

a) Subtotal colectomy

b) Proctocolectomy, pouch creation, and protective ileostoma

c) Ileo-anal anastomosis without pouch creation

d) Left colectomy with terminal colostomy

e) lleocecal resection with protective ileostoma 


\section{Supplementary material to:}

\section{Inflammatory Bowel Disease}

Crohn's disease and ulcerative colitis

by Jan Wehkamp, Martin Götz, Klaus Herrlinger, Wolfgang Steurer, and Eduard F. Stange

Dtsch Arztebl Int 2016; 113: 72-82. D0l: 10.3238/arztebl.2016.0072

\section{EREFERENCES}

e1. Halfvarson J: Genetics in twins with Crohn's disease: less pronounced than previously believed? Inflamm Bowel Dis 2011; 17: 6-12.

e2. Jostins L, Ripke S, Weersma RK, et al.: Host-microbe interactions have shaped the genetic architecture of inflammatory bowel disease. Nature 2012; 491: 119-24.

e3. Cleynen I, Boucher G, Jostens L, et al.: Inherited determinants of Crohn's disease and ulcerative colitis phenotypes: a genetic association study. Lancet. 2015; doi: pii: S0140-6736(15)00465-1.

e4. Frolkis A, Dieleman LA, Barkema HW, et al.: Environment and the inflammatory bowel diseases. Can J Gastroenterol 2013; 27: 18-24.

e5. Furrie E, Macfarlane S, Cummings JH, Macfarlane GT: Systemic antibodies towards mucosal bacteria in ulcerative colitis and Crohn's disease differentially activate the innate immune response. Gut 2004; 53: 91-8.

e6. Rutgeerts P, Goboes K, Peeters M, et al.: Effect of faecal stream diversion on recurrence of Crohn's disease in the neoterminal ileum. Lancet 1991; 338: 771-4.

e7. Joossens M, Huys G, Cnockaert M, et al.: Dysbiosis of the faecal microbiota in patients with Crohn's disease and their unaffected relatives. Gut 2011; 60: 631-7.

e8. Craven M, Egan CE, Dowd SE, et al.: Inflammation drives dysbiosis and bacterial invasion in murine models of ileal Crohn's disease. PLoS One 2012; 7: e41594.

e9. Swidsinski A, Ladhoff A, Pernthaler A, et al.: Mucosal flora in inflammatory bowel disease. Gastroenterology 2002; 122: 44-54.

e10. Darfeuille-Michaud A, Boudeau J, Bulois P, et al.: High prevalence of adherent-invasive Escherichia coli associated with ileal mucosa in Crohn's disease. Gastroenterology 2004; 127: 412-21.

e11. Behr MA, Divangahi M, Lalande JD: What's in a name? The (mis)labelling of Crohn's as an autoimmune disease. Lancet 2010; 376: 202-3.

e12. Antoni L, Nuding S, Weller D, et al.: Human colonic mucus is a reservoir for antimicrobial peptides. J Crohns Colitis. 2013; 7 : e652-64.

e13. Pullan RD, Thomas GA, Rhodes M, et al.: Thickness of adherent mucus gel on colonic mucosa in humans and its relevance to colitis. Gut 1994; 35: 353-9.

e14. Courth LF, Ostaff MJ, Mailänder-Sánchez D, et al : Crohn's disease-derived monocytes fail to induce Paneth cell defensins. Proc Natl Acad Sci USA 2015; pii: 201510084.

e15. Lord JD: Promises and paradoxes of regulatory T cells in inflammatory bowel disease. World J Gastroenterol 2015; 21 : 11236-45.

e16. Lennard-Jones JE, Shivananda S: Clinical uniformity of inflammatory bowel disease a presentation and during the first year of disease in the north and south of Europe. EC-IBD Study Group. Eur J Gastroenterol Hepatol 1997; 9: 353-9.

e17. Peyrin-Biroulet L, Loftus EV, Jr., Colombel JF, Sandborn WJ: The natural history of adult Crohn's disease in population-based cohorts. Am J Gastroenterol 2010; 105: 289-97.

e18. Henriksen M, Jahnsen J, Lygren I, et al.: Change of diagnosis during the first five years after onset of inflammatory bowel disease: results of a prospective follow-up study (the IBSEN Study). Scand J Gastroenterol 2006; 41: 1037-43. e19. Munkholm P, Langholz E, Davidsen M, Binder V: Disease activity courses in a regional cohort of Crohn's disease patients. Scand J Gastroenterol 1995; 30: 699-706.

e20. Potthast S, Rieber A, von Tirpitz C, et al.: Ultrasound and magnetic resonance imaging in Crohn's disease: a comparison. Eur Radiol 2002; 12: 1416-22.

e21. Burgmann T, Clara I, Graff L: The Manitoba Inflammatory Bowel Disease Cohort Study: prolonged symptoms before diagnosis - how much is irritable bowel syndrome? Clin Gastroentero Hepatol 2006; 4: 614-20.

e22. Farrokhyar F, Marshall JK, Easterbrook B, Irvine EJ: Functional gastrointestinal disorders and mood disorders in patients with inactive inflammatory bowel disease: prevalence and impact on health. Inflamm Bowel Dis 2006; 12: 38-46.

e23. Subramanian V, Mannath J, Ragunath K, Hawkey CJ: Metaanalysis: the diagnostic yield of chromoendoscopy for detecting dysplasia in patients with colonic inflammatory bowel disease. Aliment Pharmacol Ther 2011; 33: 304-12

e24. Solberg IC, Lygren I, Jahnsen J, et al.: Clinical course during the first 10 years of ulcerative colitis: results from a population-based inception cohort (IBSEN Study). Scand J Gastroenterol 2009; 44: 431-40.

e25. Faubion WA, Jr, Loftus EV, Jr, Harmsen WS, et al.: The natura history of corticosteroid therapy for inflammatory bowel disease: a population-based study. Gastroenterology 2001; 121: 255-60.

e26. Loftus EV, Jr, Schoenfeld P, Sandborn WJ: The epidemiology and natural history of Crohn's disease in population-based patient cohorts from North America: a systematic review. Aliment Pharmacol Ther 2002; 16: 51-60.

e27. Henriksen M, Jahnsen J, Lygren I, et al.: Ulcerative colitis and clinical course: results of a 5-year population-based follow-up study (the IBSEN study). Inflamm Bowel Dis 2006; 12: 543-50.

e28. Duricova D, Pedersen N, Elkjaer M, et al.: Overall and causespecific mortality in Crohn's disease: a meta-analysis of population-based studies. Inflamm Bowel Dis 2010; 16: 347-53.

e29. Manninen $\mathrm{P}$, Karvonen AL, Huhtala $\mathrm{H}$, et al.: Mortality in ulcerative colitis and Crohn's disease. A population-based study in Finland. J Crohns Colitis 2012; 6: 524-28.

e30. Romberg-Camps M, Kuiper E, Schouten L, et al.: Mortality in inflammatory bowel disease in the Netherlands 1991-2002: results of a population-based study: the IBD South-Limburg cohort. Inflamm Bowel Dis 2010; 16: 1397-10.

e31. Jess T, Loftus EV, Jr., Harmsen WS, et al.: Survival and cause specific mortality in patients with inflammatory bowel disease: a long term outcome study in Olmsted County, Minnesota, 1940-2004. Gut 2006; 55: 1248-54.

e32. Kingham JG, Kochar N, Gravenor MB: Incidence, clinical patterns, and outcomes of primary sclerosing cholangitis in South Wales, United Kingdom. Gastroenterology 2004; 126: 1929-30.

e33. Klag T, Stange EF, Wehkamp J: Management of Crohn's disease are guidelines transferred to clinical practice? United European Gastroenterol J 2015; 3: 371-80.

e34. Feagan BG, Fedorak RN, Irvine EJ, et al.: A comparison of methotrexate with placebo for the maintenance of remission in Crohn's disease. N Engl J Med 2000; 342: 1627-32.

e35. Hanauer SB, Feagan BG, Lichtenstein GR, et al.: Maintenance infliximab for Crohn's disease: the ACCENT I randomised trial. Lancet 2002: 359: 1541-9. 
e36. Colombel JF, Sandborn WJ, Rutgeerts P, et al.: Adalimumab for maintenance of clinical response and remission in patients with Crohn's disease: the CHARM trial. Gastroenterology 2007; 132 52-65.

e37. Louis E, Mary JY, Vernier-Massouille G, et al.: Maintenance of remission among patients with Crohn's disease on antimetabolite therapy after infliximab therapy is stopped. Gastroenterology 2012; 142: 63-70.

e38. Toruner M, Loftus EV Jr, Harmsen WS, et al.: Risk factors for opportunistic infections in patients with inflammatory bowel disease. Gastroenterology 2008; 134: 929-36.

e39. D'Haens GR, Vermeire S, Van Assche G, et al.: Therapy of metronidazole with azathioprine to prevent postoperative recurrence of Crohn's disease: a controlled randomized trial. Gastroenterology 2008; 135: 1123-9.

e40. Reinisch W, Angelberger S, Petritsch W, et al.: Azathioprine versus mesalazine for prevention of postoperative clinical recurrence in patients with Crohn's disease with endoscopic recurrence: efficacy and safety results of a randomised, double-blind, doubledummy, multicentre trial. Gut 2010; 59: 752-9.

e41. De Cruz P, Kamm MA, Hamilton AL, et al.: Crohn's disease management after intestinal resection: a randomised trial. Lancet 2015; 385: 1406-17.

e42. Campieri M, De Franchis R, Bianchi Porro G, et al.: Mesalazine (5-aminosalicylic acid) suppositories in the treatment of ulcerative proctitis or distal proctosigmoiditis. A randomized controlled trial. Scand J Gastroenterol 1990; 25: 663-8. e43. van Dieren JM, van Bodegraven AA, Kuipers EJ, et al.: Loca application of tacrolimus in distal colitis: feasible and safe. Inflamm Bowel Dis 2009; 15: 193-8.

e44. Danese S, Fiorino G, Peyrin-Biroulet L, et al.: Biological agents for moderately to severely active ulcerative colitis: a systematic review and network meta-analysis. Ann Intern Med 2014; 20 160: 704-11.

e45. Böhm SK, Kruis W: Long-term efficacy and safety of once-daily mesalazine granules for the treatment of active ulcerative colitis. Clin Exp Gastroenterol 2014; 7: 369-83.

e46. Kruis W, Fric P, Pokrotnieks J, et al.: Maintaining remission of ulcerative colitis with the probiotic Escherichia coli Nissle 1917 is as effective as with standard mesalazine. Gut 2004; 53 : 1617-23.

e47. Panaccione R, Ghosh S, Middleton S, et al.: Combination therapy with infliximab and azathioprine is superior to monotherapy with either agent in ulcerative colitis. Gastroenterology 2014; 146 392-400.

e48. Simillis C, Purkayastha S, Yamamoto T, et al.: A meta-analysis comparing conventional end-to-end anastomosis vs. other anastomotic configurations after resection in Crohn's disease. Dis Colon Rectum 2007; 50: 1674-87.

e49. Bernell 0, Lapidus A, Hellers G: Recurrence after colectomy in Crohn's colitis. Dis Colon Rectum 2001; 44: 647-54.

e50. Larson DW, Dozois EJ, Piotrowicz K, et al.: Laparoscopic-assisted vs. open ileal pouch-anal anastomosis: functional outcome in a case-matched series. Dis Colon Rectum 2005; 48: 1845-50. 


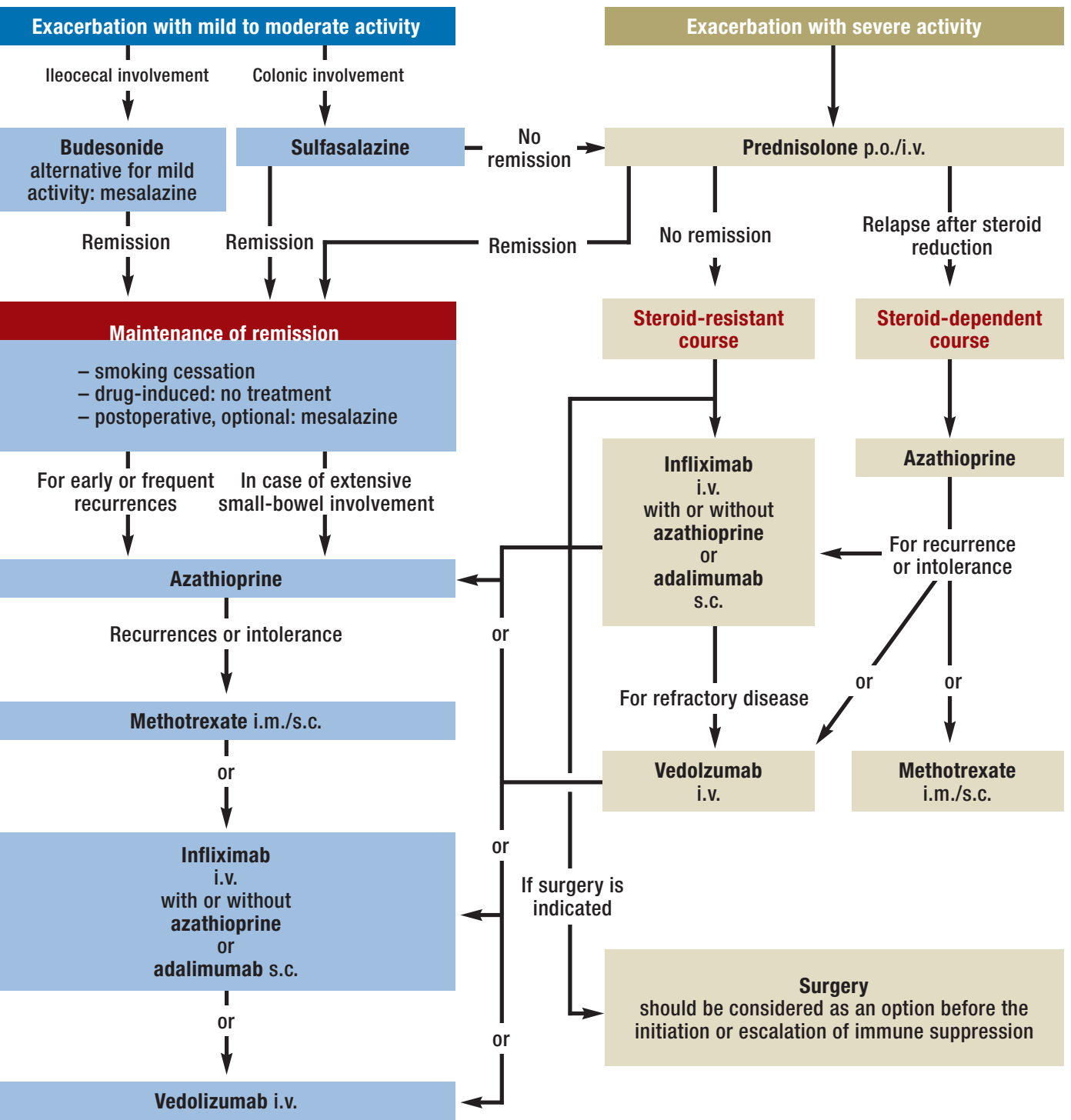




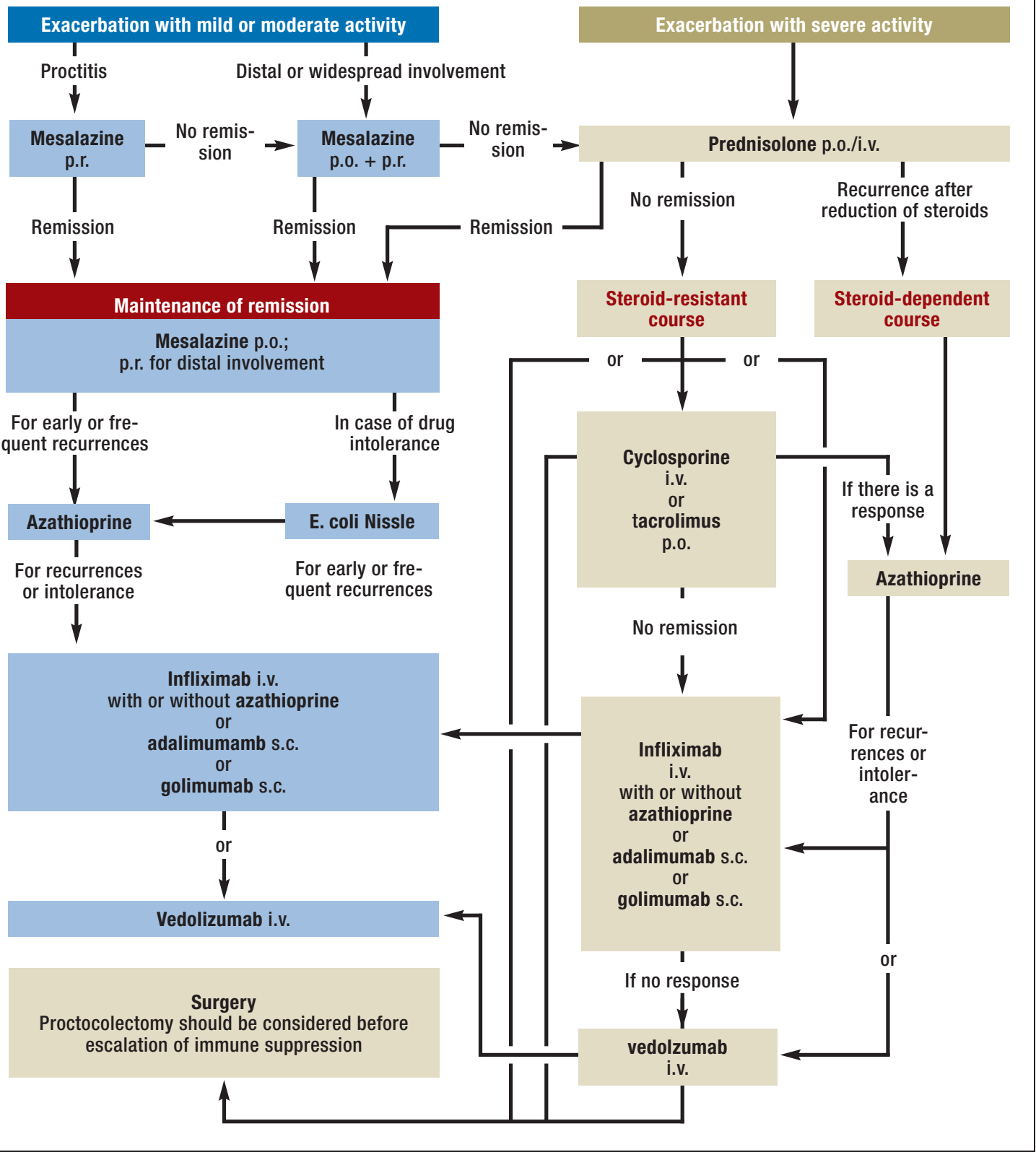

